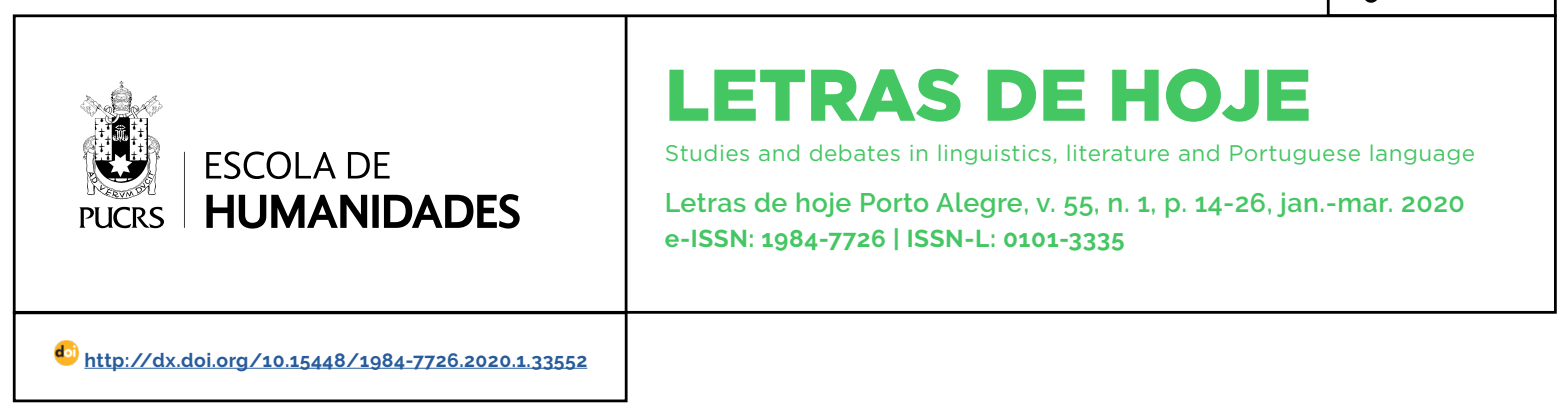

\title{
Intermidialidade na literatura brasileira contemporânea
}

\author{
Intermediality in Brazilian contemporary literature ${ }^{1}$ \\ Intermedialidad en la literatura brasileña contemporánea
}

\section{Ana Cláudia Munari Domingos $^{2}$}

orcid.org/0000-0002-6629-588X

ana.c.munari@gmail.com

Recebido em: 12 mar. 2019. Aprovado em: 18 nov. 2019. Publicado em: 14 abr. 2020.

\section{(c) (i)}

Artigo está licenciado sob forma de uma licença Creative Commons Atribuição 4.0 Internacional.
Resumo: A questão sobre a influência das práticas em hipermidia na literatura tem emergido a partir de estudos de vários campos, desde a aprendizagem da leitura, com a hiperleitura, até a questão dos gêneros, por exemplo, o retorno das narrativas jornalisticas e do romance-reportagem. Neste trabalho eu trago apenas uma pequena parte de uma extensa pesquisa que vem sendo feita nos últimos quatro anos, em cuja fase atual vem analisando a literatura brasileira contemporânea para identificar tendências, questões estéticas, formais, que possam demarcar alguma mentalidade do nosso tempo, sobretudo essa que diz respeito ao modo como hoje as mídias convergem, numa relação reciproca com as práticas de leitura. Para tanto, analisamos duas obras do corpus da pesquisa a partir dos estudos de Intermidialidade, entendendo as estratégias ficcionais da autoficção e da metaficção como fenômenos intermidiais.

Palavras-chave: Intermidialidade. Metaficção. Autoficção. Literatura brasileira. contemporânea.

Abstract: The issue about the influence of practices in hypermedia in the literature has been observed from several fields, since the learning of reading to hyper-reading, and the question of genres as well, for example, the return of journalistic narratives and book-reportage. In this paper I bring only a small part of an extensive research that has been done in the last four years, in which the current phase is analyzing contemporary Brazilian literature to identify tendencies, aesthetic and formal issues that could demarcate some of our time's mentality, especially the one that concerns the way in which the media converge today, in a reciprocal relationship with the practices of reading. From this purpose, we analyze two novels of the corpus of the research from the studies of Intermidiality, understanding the fictional strategies of autofiction and metafiction as intermedial phenomena. Keywords: Intermediality. Metafiction. Self-fiction. Brazilian Contemporary Literature.

Resumen: El tema de la influencia de las prácticas hipermedia en la literatura ha surgido de estudios en diversos campos, desde el aprendizaje de la lectura, con la hiperlectura, hasta la cuestión de los géneros, por ejemplo, el regreso de las narrativas periodisticas y de la novela-reportaje. En este artículo traigo solo una pequeña parte de la extensa investigación que se viene realizando desde los últimos cuatro años, en cuya la que en la fase actual se ha analizado la literatura brasileña contemporánea para identificar tendencias, cuestiones estéticas y formales que pueden demarcar alguna mentalidad de nuestro tiempo, especialmente la que se refiere a la forma en que los medios convergen hoy, en una relación reciproca con las prácticas de lectura. Por lo tanto, analizamos dos obras del corpus de investigación a partir de los estudios de Intermedialidad, entendiendo las estrategias de ficción, autoficción y metaficción como fenómenos intermediales. Palabras clave: Intermedialidad. Metafiction. Autoficción. Literatura brasileña. contemporánea

Trabalho apresentado no The 4th International Conference of the International Society of Intermedial Studies - Intermedial Practice and Theory in Comparison - em Hangzhou Normal University, China, 15-17 nov. 2018.

Universidade de Santa Cruz do Sul, Santa Cruz do Sul, RS, Brasil. 
É sabido que a literatura, como artefato cultural, faz convergir as transformações e mudanças sociais, sobretudo quando novas mentalidades se desenvolvem e fazem surgir novos modos de dizer. E novos modos de dizer têm sentido em novas linguagens, suportes e formas. Estagnadas certas discussões sobre o fim do livro com a chegada da internet e do ebook, a compreensão sobre para onde vai um dos principais conteúdos do livro - a literatura - ainda é incipiente. De um lado, estão aqueles que, mais em defesa do que propriamente por convicção, entendem que a literatura segue e seguirá sendo o que é: prosa e poesia - seja no livro, seja no ebook. De outro, aqueles que apontam o fim da literatura no fim da leitura literária: quando o último leitor deixar de ler, ela deixará de existir.

A literatura, que veio depois do teatro e que é anterior ao livro, já "sobreviveu" ao rádio, ao cinema, à televisão, e mesmo à internet, apesar da crise do mercado livreiro, vide o sucesso de livros lançados por youtubers. Mas essa afirmação não ignora o fato de que as novas gerações cada vez mais têm escolhido os audiovisuais como forma de acessar histórias, experienciar a ficção, ter contato com o mundo do simbólico - o que inclui duas das mídias que talvez tenham feito muitos leitores trocarem as histórias em papel por aquelas das quais podem ser protagonistas: os jogos digitais, em consoles e computadores, e as séries televisivas, sobretudo as produzidas para os serviços de streaming.

Apesar dessas migrações, não podemos esquecer do fenômeno da narrativa transmídia (JENKINS, 2015), que promove, na indústria do entretenimento, que essas midias se cruzem, para atrair diferentes receptores e fazer com que eles circulem - e consumam - diferentes produtos de mídia e, assim, tenha acesso a um universo mais amplo de histórias e personagens o que sempre significa o consumo de novos produtos. Nesse seguimento, cinema, teatro, televisão, internet, são tipos de mídias qualificadas que têm usado, desde que as tecnologias digitais cada vez mais permitem a convergência de linguagens, estratégias e técnicas umas das outras, cada vez mais mostrando a qualidade intermidial dos produtos de mídia.

É assim que, por exemplo, quadrinhos, séries de televisão, cinema e jogos se imiscuem para construir um universo único, do qual emanam elementos - espaços diegéticos, personagens, enredos - que se constroem por convergência entre as midias, tornando indistinguiveis suas fronteiras. A literatura, muitas vezes, serve de alimento para a criação desses universos transmidiais e, inserida nesse espaço cinemático e digital, deixa de ser reconhecida também como arte criadora. Sua antiguidade como forma de expressão cultural e sua intensa conexão com a mídia livro costuma reforçar esse não reconhecimento, como se a mera transmidiação a desconfigurasse como arte. Isso significa que há elementos que são típicos da literatura e cuja presença é exigida para que ela seja tomada como tal - sem isso não apenas a reconheceriamos como não seria viável uma ciência da literatura. É assim que podemos dizer que um romance escrito há um século pode guardar muitas semelhanças com um recém-publicado em ebook.

Para serem compreendidos como literatura, certamente os produtos de mídia precisam responder a determinados critérios - e aqui nem vamos discutir a questão entre os clássicos, os best-sellers e a nova categoria middlebrow. Para a Intermidialidade, elas são tipos de midias qualificadas, porque há certas qualidades que justamente emolduram essas midias, qualidades essas que Elleström (2017) descreve como materiais, sensoriais, espaçotemporais e semióticas. O que define uma mídia, assim, tem sentido na materialidade técnica, no modo como é percebida, na relação entre o conteúdo, sua produção e leitura e a perspectiva espaçotemporal e no seu modo de representação, assim como em questões culturais e de mercado. Assim, essas narrativas que seguem sendo contadas em palavras permanecem sendo publicadas como contos, romances, novelas, ficção.

Por outro lado, se a moldura da literatura é, nesse sentido, inquebrável, ela também é porosa, e permite-se ser atravessada pelas linguagens que circulam no mundo. O romance 
é um bom exemplo dessa heterogeneidade, que é mesmo sua característica, pelo uso que faz de outras midias qualificadas, por exemplo, a carta, como elementos de seu próprio discurso. Essa porosidade da literatura pode ser uma ponte para o diálogo com outras mídias, caracterizando a intermidialidade como a nova intertextualidade. É importante ressaltar que mesmo um texto literário centenário midiado por um livro pode ser lido em convergência com outras mídias, visto que nossa leitura, sempre transtextual, influenciada hoje pelas práticas com a internet, tem sido bastante intermidial, ou hipermidial, para usar o termo que diz respeito à linguagem da internet. De qualquer forma, a neurociência já tem mostrado como as práticas de produção e leitura com a hipermídia têm treinado nosso cérebro para a busca axial de insumos (CARR, 2011), ainda que leiamos no antigo e eficiente livro de papel.

A questão sobre a influência da hipermidia na literatura tem emergido a partir de estudos de vários campos, desde a aprendizagem da leitura, com a hiperleitura, até a questão dos gêneros, por exemplo, o retorno das narrativas jornalísticas e do romance-reportagem. Neste trabalho eu discuto apenas uma pequena parte de uma extensa pesquisa que vem sendo feita nos últimos quatro anos. Através desta pesquisa, meu grupo vem analisando a literatura brasileira contemporânea para identificar tendências, prospectando não um viés historicista - embora isso seja inevitável em vista da comparação -, mas mudanças estéticas, formais, que possam demarcar alguma mentalidade do nosso tempo, sobretudo essa que diz respeito ao modo como hoje as midias convergem, em uma relação reciproca com as práticas de leitura.

Na primeira versão do projeto, tratamos das práticas de leitura e de escrita empíricas, através de entrevistas com cerca de 300 estudantes da universidade sede do projeto, a Universidade de Santa Cruz do Sul, incluindo aí questões sobre a leitura literária. E nossa principal conclusão foi o entendimento de que a prática mais comum de leitura e de escrita, que eu chamei de Deslizamento, é aquela em que os leitores deslizam pelos textos
- surfam pela superfície, escorregam pelas vias -, e esses textos são, sobretudo, pictóricos e audiovisuais e fragmentos de textos verbais. Mesmo quando leem o texto verbal em livro impresso, ainda assim, esses leitores interrompem o fluxo, seja para dialogar com a leitura em foco, seja para marcar presença no espaço virtual. Ou seja, as práticas de leitura dos entrevistados mostraram-se bastante hipermidiais, prática essa que deu origem ao termo hiperleitura.

Na segunda fase, dirigimos então nosso olhar para os produtos de mídia, elegendo o romance contemporâneo brasileiro, para tentar encontrar tendências que pudessem demarcar tanto uma diferença na literatura contemporânea quanto sua relação com as práticas de leitura hodiernas. 0 primeiro problema foi formalizar um corpus. Como o principal gênero de leitura literária era o romance, conforme a pesquisa anterior, o produto de mídia escolhido foi o romance em língua portuguesa, também por ser a minha área de pesquisa de origem, desde que eu ensino a literatura em língua portuguesa nos cursos de graduação. Buscando uma forma de limitar esse corpus, que é imenso, pensamos em premiações e seleções literárias. Então encontramos a edição da Revista inglesa Granta, que publicou um volume com os "20 melhores jovens escritores brasileiros". Desses 20, 15 romances foram lidos (as únicas publicações disponiveis à época), evidenciando-se que todos eles apresentavam narradores em primeira pessoa. Entendemos que poderia ser uma tendência, que foi confirmada por muitos críticos naquele momento. Então decidimos formalizar o corpus, além dos romances escritos pelos autores presentes na Granta, a partir de dois dos principais prêmios de literatura em língua portuguesa, o "Jabuti" e o "Oceanos", demarcando nosso foco a partir do ano de 1994, com a entrada da internet comercial, e passamos a estudar o narrador. E confirmamos a repetida ocorrência da escrita em primeira pessoa, que foi, naquele momento então bastante apontada pela crítica como uma tendência (DALCASTAGNĖ, 2012; FIGUEIREDO, 2013).

Nessa segunda fase, o uso frequente do narrador em primeira pessoa resultava, 
muitas vezes, nas estratégias da autoficção e da metaficção, enquanto a metaficção surgia também em romances em terceira pessoa. Outra evidência, que buscamos analisar na terceira fase, são os fenômenos intermidiais, como o uso da linguagem não verbal, visto que eles se mostraram frequentes na segunda fase da pesquisa. Neste trabalho, assim, discuto sobre duas dessas tendências, a autoficção e a metaficção, para mostrar como elas podem ser compreendidas como fenômenos intermidiais. Opsanie Swiata (2013), romance de Verônica Stigger, faz uma colagem de referências e inclui imagens. Divórcio (2012), de Ricardo Lísias, também inclui imagens e, ao traçar uma relação indexical com o universo extradiegético, faz quebrar a moldura entre a ficção e a não ficção. Ambos colocam em questão a própria escrita ficcional e, assim, o próprio universo da representação.

Essas duas tendências envolvem perspectivas que justamente têm sentido na própria constituição do romance brasileiro contemporâneo - ou o próprio romance - como um tipo de mídia qualificada: a questão das molduras do gênero romanesco em relação ao seu contrato com a ficção e o distanciamento do autor, demarcados na origem do romanesco no século XIX; e sua constituição como arte da palavra, além das tendências aqui apresentadas. Projeta-se nessas duas questões o gene do romance: um modo de narrar que tem sentido no sujeito, senão como expressão de certa visão de mundo, visão emocional, também como modo de narrar, a partir desse eu que, falando de si ou do outro, sempre fala de si. É um gene egocêntrico: esse sujeito, sua visão do mundo, seus modos de dizer, atravessam os anos sem perder a moldura do romanesco, ainda que algumas fronteiras sejam esboroadas pela relação com outras mídias e com as práticas sociais. Nesse sentido, parecenos que a mentalidade contemporânea é própria para essa exacerbação desse herói romanesco.

A presença de recursos de outras mídias como o cinema, a poesia, o jornalismo - e a evidência do movimento do narrador - entre um eu ficcional e um eu empírico e intermidial, pode se mostrar uma tentativa de apreender um presente em movimento que, ao mesmo tempo em que parece seguir certa direção, pode restar em ser irônico, paródico, alegórico - tão sólido que se desmancha no ar (BAUMAN, 2000). Nossa observação deste "presente em movimento" está centralizada também no pensamento de vários pensadores do contemporâneo, como Gilles Lipovetsky, Christopher Lasch, Jean-François Lyotard, Guy Debord, que configuram uma sociedade pós-moderna cujas caraterísticas apontam para o individualismo, o narcisismo e o hiperconsumo controlado pelo desejo, o que configura certo uso das mídias como forma de ser e estar no mundo. A análise das manifestações culturais contemporâneas, profundamente demarcadas por tecnologias e estratégias de midiação - quando evocamos a "Cultura das mídias" e a comunicação ubíqua descritas por Santaella (2013) -, deve levar em conta em que medida os novos meios moldam uma mentalidade pós-moderna, que "exalta o individualismo, abarcando todos os aspectos da vida social. Leva o culto ao corpo (narcisismo corporal) e a liberdade pessoal até o extremo." (GARCÍA-CAPILLA, 2011, p. 223, tradução nossa). ${ }^{3}$

Não me cabe aqui demarcar, através da percepção dessas tendências, uma visão historicista, quando falo em "mentalidade pósmoderna" - e que poderiamos pensar também como uma condição pós-moderna (LYOTARD, 2010). A intenção é falar mesmo do presente, mas seria incoerente não buscar certo paradigma de mudança quando se fala em tendências. Para pensarmos essa convergência de sintomas, poderíamos, talvez, trazer a ideia de uma cultura globalizada, mas é uma situação que sabemos não apenas que é inviável, como também, ao contrário, que ela acaba por reforçar a ideia de cultura como construção de identidades - uma verdade difícil de contestar, que quebra o senso da globalização. Assim, quando encontramos

\footnotetext{
3 Do original: exalta el individualismo, abarcando todos los aspectos de la vida social. Se rinde culto al cuerpo (narcisismo corporal) y a la liberación personal hasta extremos desconocidos
} 
coincidências, repetições - os sintomas - em obras que já têm definidas certas identidades - a brasileira, a urbana - convém evocarmos práticas que, através do compartilhamento e das experiências em comum, possam estar fazendo eclodir novas práticas culturais. Entendo esse exercício compartilhado - as novas práticas culturais - como o uso das midias digitais: para ver, escutar, produzir conteúdo: acessar esse mundo do consumo como uma via onde se navega como um semionauta da cultura (BOURRIAUD, 2009).

Nossa navegação como semionautas só vem a exacerbar o mundo dos objetos e de seu consumo, tornando-os elementos para a pósprodução, quando é através da ressignificação do já dado que garantimos espectadores para nossos espetáculos particulares (DEBORD, 1997). Usamos as mídias para transmidiar o já midiado, para repetir e ressignificar. Christopher Lasch (1990), por exemplo, identifica certos traços caracteristicos de uma "sociedade pós-industrial" já nos anos 70 do século passado, demarcando-a no "consumo e na sedução", e colocando seus indivíduos como "sitiados" diante da instabilidade do mundo e de uma iminente catástrofe:

A atual preocupação com a "identidade" expressa em certa medida esse embaraço em se definir as fronteiras da individualidade. E também faz o estilo minimalista da arte e da literatura contemporâneas, que extrai grande parte de seus motivos da cultura popular, em particular da invasão da experiência pelas imagens, e deste modo ajuda-nos a ver que a individualidade mínima não é só uma resposta defensiva ao perigo mas se origina de uma transformação social mais profunda: a substituição de um mundo confiável de objetos duráveis por um mundo de imagens oscilantes que torna cada vez mais dificil a distinção entre a realidade e a fantasia (LASCH, 1990, p. 12-13).

As décadas seguintes parecem ter intensificado essas "imagens oscilantes" e obnubilado ainda mais a "distinção entre a realidade e a fantasia". Essa sociedade, então profundamente arraigada ao uso das mídias digitais, é aquela a partir da qual se multiplica a mais antiga forma de expressão: aquela que coloca o falante em primeiro plano. A proliferação de blogs, de perfis pessoais, de aplicativos de fotografia e de vídeos, a prática do jornalismo que publica mensagens, fotos e audiovisuais produzidos pelos leitores, tudo isso é consequência não apenas do canal que atualmente é disponibilizado a uma grande parcela da população através da internet, mas de toda uma tecnologia midiática que nos permite prescindir do outro, como mostra Lipovetsky (2006) ao falar de como o consumo tem sido centrado no individuo.

Um dos focos do entendimento desse contexto pode voltar-se para o impacto na sociedade a partir da mudança do paradigma do indivíduo que consome para aquele que produz conteúdo, um protagonista na esfera cultural - esse semionauta ou o textual poacher (JENKINS, 1992) ou um novo protagonista:

As novas midias não apenas geraram essa primazia da sociedade como protagonista de suas próprias histórias, mas também as histórias de 'pessoas comuns' começaram a prevalecer nas mídias tradicionais, como no caso de televisão, ou no cinema, em histórias. cujos protagonistas são os mesmos cineastas. (TORRADO et al., 2011, p. 11. tradução nossa. $)^{4}$

Se podemos colocar a autoficção e a metaficção como tendências da literatura brasileira contemporânea produzida por esse sujeito, talvez seja pertinente que nos perguntemos por que escritores passaram a construir narradores que trazem seus biografemas (BARTHES, 1984) e que se colocam entre o mundo e a ficção. Se as motivações para a escrita em primeira pessoa envolvem questões bastante subjetivas, cujas tentativas de resposta poderiam restar em mera especulação, sabemos que o fato de podermos falar de nós mesmos nas redes ou publicarmos e compartilharmos nossos selfies diz respeito ao fato de que temos dispositivos - mídias e softwares - para isso. O fato de que usamos as

4 Do original: No solo los nuevos medios han generado esta preeminencia de la sociedad como protagonista de sus propias historias, sino que también en medios tradicionales como la televisión o el cine han comenzado a primar las historias de "gente corriente", en el caso de la primera, o historias cuyos protagonistas son los mismos creadores de las películas en el cine. 
mídias para nos colocarmos em foco parece ter sentido naquela ideia já aqui colocada, sobre como cada vez mais podemos prescindir do outro e organizar nossas vidas em torno de nós mesmos. É assim que o mundo de mídias pelo qual navegamos é cada vez mais visto "atrás de nós" - e "menor", "fora de foco", a partir de uma perspectiva ao controle de nossas mãos/lentes. É nesse sentido, que traz certo esvaziamento pela falta de alteridade, que as próprias mídias e seus agentes se tornam matéria da ficção, caso da autoficção e da metaficção.

Antes da análise a que nos propomos, precisamos sintetizar o que entendemos por autoficção e metaficção para esse trabalho, a partir da Intermidialidade, salientando que não é nossa intenção discutir os conceitos, mas mostrar como eles surgem, a partir do contexto já aqui explorado, nas obras que aqui trazemos. Entendemos que a autoficção ocorre quando o narrador homodiegético tece paralelos com um narrador extradiegético, confundindo-se com o autor, pessoa empírica fora da diegese. Já a metaficção é construida por um narrador que faz confundir-se como autor e escritor, em um nível metadiegético, discutindo a própria escrita ficcional. Ambos são fenômenos intermidiais: a autoficção porque ocorre a partir do atravessamento entre o que compreendemos como os tipos de mídia qualificadas Romance e Biografia, visto que o primeiro usa estratégias do segundo; a metaficção porque, ao colocar em cheque o próprio tipo de mídia qualificada, o Romance, faz dele uma representação - mostra-o como mídia. Em ambos os casos, há ainda o uso de mídias não verbais, como estratégias para a autoficção e para a metaficção.

Para a Intermidialidade, a própria mídia é um signo - quer dizer: atrai nossa atenção semiótica, o que significa que a Intermidialidade muitas vezes se auxilia da Semiótica para compreender os fenômenos intermidiais, visto que é através dela que podemos analisar o significado. Não é à toa que Elleström (2017) chamou a quarta modalidade das mídias de semiótica, é porque a Semiótica é chamada para a compreensão das representações signicas que ali se realizam. Em vez de lermos um romance focalizando a história que ele nos conta, sem nos preocuparmos com o que ele significa, como mídia. Na Intermidialidade nos perguntamos sobre o que o romance está fazendo como Romance - o que caracteriza um olhar metaficcional - ou o que o Romance está fazendo com outras mídias. Essas perspectivas de análise desembocam, sempre, em diferentes formas de compreender a própria obra.

$\mathrm{Na}$ Literatura Comparada, espaço da Intermidialidade, isso envolve pensar, também, o que seja literariedade, ficção, poesia e atender às perguntas que fazemos diante das mudanças e tendências da literatura quando elas envolvem as relações com outras mídias - e muitas vezes as mudanças e tendências estão relacionadas a essas interações. No caso de um romance, por exemplo: à medida que certo afastamento do Tipo de Midia Qualificada Romance vai aumentado, na relação com uma ou mais mídias, outra Mídia pode começar a se formar dessa relação. $O$ Tipo de Midia Qualificada Romance emoldura histórias de ficção. Se o produto de mídia traz uma história que aconteceu no mundo extratextual ${ }^{5}$ e não criada no ato da escrita, o Tipo de Mídia Qualificada é uma Biografia.

Recentemente, no entanto, a autoficção se mostrou um esboroamento do Romance, ao romper a moldura entre o que seja ficção realidade factual produzida no ato da escrita - e "realidade" - acontecimento extratextual produzido no espaço-tempo anterior ao texto. Assim que leitores começaram a identificar personagens e acontecimentos dos romances que liam com certas existências extratextuais,

\footnotetext{
5 Não vamos entrar na questão da relação entre ficção e realidade factual extratextual, visto que já é sabido que o ato de narrar, per se, já produz ficção. A questão aqui é entender a "realidade" (que é sempre incaptável) como um acontecimento extratextual, que será narrado com outra intenção. É interessante apontar que muitos elementos dos romances têm existência fora do texto, porque a vida e as experiências dos escritores é que são a matéria da ficção, mas seu entrelaçamento, seus personagens e seus episódios não são os mesmos, porque enredados em direção à ficção. A perspectiva mais importante, talvez, está em entender a intenção: na Biografia, a intenção é se aproximar o mais possivel daquele acontecimento extratextual e das pessoas ali representadas, enquanto no Romance, na ficção, existe o desejo da criação, da produção do novo. Essa questão é discutida em Intermidialidade: objetos, teorias, práticas (DOMINGOS, no prelo).
} 
conforme a intenção dos produtores desses produtos de mídia (autores e editores, às vezes críticos), o termo romance autoficcional começou a ser mencionado. Vejamos que a inserção de fotografias em um romance pode provocar esse rompimento, à medida que o leitor pode entender as pessoas, coisas e lugares representados como um signo da realidade extratextual, ou seja, como biografemas, indícios de vidas "reais" que existiram fora do texto.

No romance contemporâneo brasileiro, muitas vezes essas estratégias de confundir o universo diegético com o universo extradiegético, que se mostra dentro da mentalidade da pós-verdade que está sendo bastante discutida (através das questões sobre o que seja "verdade", o que seja "ficção"), utiliza linguagens não verbais, principalmente fotografias, mas também a própria linguagem gráfica, cuja forma de representação não é a mesma da palavra, configurando um atravessamento intermidial que pode ser entendido como a presença de outro eu, o escritor/editor. Esse entendimento nos fez entender que podiamos investigar essas estratégias a partir da Intermidialidade.

Em Divórcio (2013), romance de Ricardo Lísias, o título pode ter um sentido duplo, evocando não apenas a separação judicial entre o narradorprotagonista e sua esposa, mas também o divórcio entre ele e esse mundo - então distorcido -, que passar a ser um outro - aquele que contraria seu sentimento, sua opinião, seu desejo e sua decisão sobre as coisas: é uma quebra de alteridade que coloca "atrás de si", como em uma selfie, todo o contexto - o espaço e as personagens, que podemos pensar como a diegese, então bastante controlada por esse narrador que finge não ser onisciente (pois o que ele nos conta seria apenas experiência e testemunho). Ricardo Lisias - o autor, narrador, escritor e protagonista - utiliza a estratégia de escrever um diário, uma boa maneira de ignorar o leitor e traçar um diálogo consigo mesmo. A imposição de sua fala sobre o outro é tão evidente que, mesmo quando há o diálogo, ele é tomado sob o controle discursivo do narrador, a partir de uma perspectiva em primeira pessoa. Por exemplo, ele compartilha alguns trechos do diário de sua esposa, mas apenas aqueles que corroboram sua teoria, não o todo, e essa seleção acaba por ser a sua seleção, sendo, assim, tomada a partir dele mesmo.

O nome do narrador homodiegético é Ricardo Lísias, assim como o autor, entre os quais há outras várias coincidências - cidade e data de nascimento, emprego, formação acadêmica e profissional e, principalmente, o fato de que ele também é divorciado - que é a intriga central do romance em sua relação com a motivação: a prática do jornalismo brasileiro. $\mathrm{O}$ tempo todo esse narrador nos aponta lugares e acontecimentos muito familiares, por exemplo, a Corrida Internacional de São Silvestre (uma maratona que ocorre anualmente em São Paulo). Paralelamente, há no romance a inserção de várias fotografias, grande parte delas trazem cenas de familia e, em algumas delas, há a imagem de um menino. O narrador não conecta as imagens ao enredo, e o leitor precisa criar alguma conexão para entender o que as imagens podem representar, relacionadas à história. Como o narrador fala sobre sua vida a partir de um trauma, podemos entender essas imagens como indices de sua vida, fora da diegese fictícia. A combinação palavra-imagem que é dada pelo livro, como um produto de mídia técnico, não se dá na mídia qualificada romance, visto que é o leitor que precisa tecer interações entre os elementos da história e as fotografias. Da mesma forma, é o leitor que precisa relacionar os dados biográficos do personagem-narrador aos biografemas do autor. No Facebook, por exemplo, Ricardo Lísias, autor, postou fotos de sua participação na maratona já citada. Os índices dados pelo produto de mídia - a coincidência nominal, o diário e as fotografias - podem induzir o leitor a buscar conferir se os outros elementos também são indiciais. O resultado é que esse cruzamento entre as mídias e a mudança no modo de representação leva o leitor entender que não é ficção, não é romance - é biografia, é um diário, é tudo verdade - e que verdade?

A escrita autoficcional de Divórcio faz convergir 
e, assim, confundir, não apenas as figuras do autor (como individuo empírico) e do narradorprotagonista, mas também, e talvez com mais pertinência, as instâncias da invenção e do referente real (ou entre o verossímil e o real). Quando falamos de nós como se (RAJEWSKY, 2012a, 2012b) fôssemos nós mesmos, em primeira pessoa, a partir de nosso biografemas - nome, idade, profissão etc. -, invocamos nossas experiências, nosso passado factual (afinal, é esse passado que nos faz sermos quem somos). Em Divórcio, a escolha do autor por contar uma história que em muitos aspectos cola à sua elementos passiveis de serem confirmados através da rede social do autor, como nome, local e ano de nascimento, profissão, alguns interesses, evocando, assim, um hiperleitor - já trouxe bastante polêmica e discussão. É interessante que alguns trabalhos que analisam a obra do autor insistem em, por exemplo, acrescentar o nome da esposa do autor ou afirmar que ela realmente o teria processado - sem um "é possivel", quando nem os elementos do livro ou das redes sociais podem corroborar tais assertivas - e o que isso interessaria para a compreensão estética da obra é outra questão, que não discutirei aqui.

Assim que seu livro passou a ser objeto de comentários que evocavam dados factuais do Lísias empírico, o autor passou a comentar sobre esses elementos nas redes sociais, transmidiando os sentidos da obra para além das palavras que compõem o romance, em uma interessante combinação de mídias pós-produção que ajudou na construção de significado para o romance. O romance Divórcio, de Ricardo Lísias, é a obra mais vendida do autor, que the rendeu muitas entrevistas, aparições em programas de televisão, muitos leitores e certa boataria que, de certa forma, prejudicou a compreensão da obra, que é muito mais do que uma história de traição e vingança ou uma grande fofoca, como alguns leitores acreditam que seja. Certamente os leitores sabem que é ficção, mas, ao mesmo tempo, entendem que o autor usa a literatura para mostrar a verdade. De certa forma, ele usa a literatura para mostrar a verdade, mas não a verdade da narrativa, mas daquilo que ela representa e que tem bastante sentido na crítica ao exercício do Jornalismo (HOHLFELDT; DOMINGOS; SILVA, 2017).

A partir da Intermidialidade, a questão central dessa obra é a forma, pois ela é usada como elemento significante - não é só a narrativa e o uso da linguagem verbal, em sua representação simbólica, pela palavra, que constrói a obra, mas a narração e sua combinação com outras mídias cuja representação é mais indicial - caso do diário e da fotografia. Na escrita ficcional, a construção diegética se dá por representação icônica da realidade externa. No diário e na fotografia, essa representação é, sobretudo, indicial. ${ }^{6}$

O diário, as fotografias e os outros biografemas são usados, assim, como índices para "a verdade está lá fora", mas essa "verdade" é condicionada pela verossimilhança - afinal, está escrito na ficha catalográfica que se trata de ficção. Essa "verdade", dada pela forma, tem sentido naquilo que toda arte busca representar, uma verdade emocional ou social. No caso de Divórcio, há o questionamento sobre a própria realidade, sobre o modo como contamos histórias e, mais especificamente e de um modo diretamente crítico, como os jornalistas produzem notícia. A combinação entre essas mídias - o romance, a biografia e a fotografia -, assim, é o modo de estabelecer essa conexão com a verdade, que depende bastante da participação do leitor. Compreender essa conexão como uma estratégia ficcional para criar personagens e seus dramas de forma indicial, a fim de torná-los verossimeis para essa "verdade social", permite que teçamos uma relação com o modo como os artistas podem manipular ícones, assim como os jornalistas podem manipular a realidade. E essa é a chave para entender esse produto de mídia, uma crítica irônica ao jornalismo, não uma fofoca sobre uma mulher traiçoeira. 
Se a autoficção, para ser um fenômeno intermidial, depende do como é construída e também do agenciamento do leitor, a metaficção é sempre intermidial. No romance Divórcio uma história que traz uma das mais profundas metáforas da depressão - a perda da pele -, essa elaboração entre realidade e invenção, autor e narrador-protagonista é duplamente erigida pela metaficção. Por exemplo, o narrador-protagonista faz referências a biografemas do autor - à sua obra: "Será que tudo não passa de um conto que estou escrevendo? Senti uma enorme pressão na cabeça. Já aconteceu com uma personagem minha, o Damião" (pos. 53 de 2801)7, "Só pode ser ficção. No meu último romance, $O$ céu dos suicidas, o narrador enlouquece e sai andando. Agora, fiquei louco e estou vivendo minhas personagens" (pos. 153), "'Meus três Marcelos' não cita o nome do nosso jurado $[X]$ e muito menos a piada que foi o Festival de Cannes de 2011" (pos. 2058). Ou faz referência ao próprio processo de escrita, que traria elementos de sua biografia: "Acabo de achar a folha com frases autobiográficas que redigi naquele dia. Um pouco abaixo do meio, depois do comentário sobre o enterro da minha vó, escrevi várias vezes com caneta vermelha: ACONTECEU NÃO É FICÇÃO". Ou seja, a estratégia de escritura metaficcional aqui é evidente: confundir os limites entre a evocação da memória autobiográfica e a invenção, neste caso, a partir dos biografemas: "Passei dez dias esquematizando esse trecho, mas consegui pouquissima memória"; (pos. 435).

A metaficção é sempre um fenômeno intermidial porque não é uma referência ao texto em si, como acontece na metatextualidade, ou uma virada sobre a linguagem, como na metalinguagem, nem ao conteúdo de outra obra, como a intertextualidade, mas à ficção - neste caso, ao romance, à mídia qualificada romance. Por isso, é uma referência de mídia, um produto de mídia que se refere a um tipo de mídia qualificada, neste caso, ele mesmo. Aqui, no entanto, vamos tratar da metaficção, como um fenômeno intermidial de representação de mídia, através da obra Opsanie Swiata, de Verônica Stigger. Embora seja um romance brasileiro, o título é polonês e significa "a descrição do mundo". Em sintese, a história é uma narrativa de viagem, a viagem de Opalka, um polonês, por trem e barco, para conhecer o filho que está em seu leito de morte na Amazônia. Nessa viagem, surgem vários personagens e suas histórias, que Opalka vai anotando no seu caderno. São tantos os subenredos, que em certo momento é dificil traçar relações entre eles e a história. É dizer que no caminho de Opalka há muitas vidas, o mundo não para nesse movimento da viagem do protagonista. Sobre esses diferentes personagens e suas histórias, é possivel que o leitor perceba que existem muitas referências a personagens e a elementos de outras obras. Por exemplo, o casal Andrade, passageiros do navio, é composto de uma pintora e um poeta, ambos moradores de São Paulo. Há cenas surreais que parecem deslocadas da história. Mesmo o leitor que não consiga enxergar as referências percebe que há, ali, um quebra-cabeças de histórias.

O livro traz várias imagens - o projeto gráfico do livro é digno de uma análise à parte -. representações fotográficas que parecem ilustrar a viagem, embora não sejam referidas pelo narrador. É assim que há páginas inteiras mostrando, por exemplo, a propaganda de uma viagem de navio, um cartão postal, o interior de um navio e pequenos bilhetes que parecem ser instruções de viagem. O narrador em primeira pessoa ainda incluiu as missivas trocadas com seu filho e os avisos do comandante do navio (Figuras 1 e 2). 

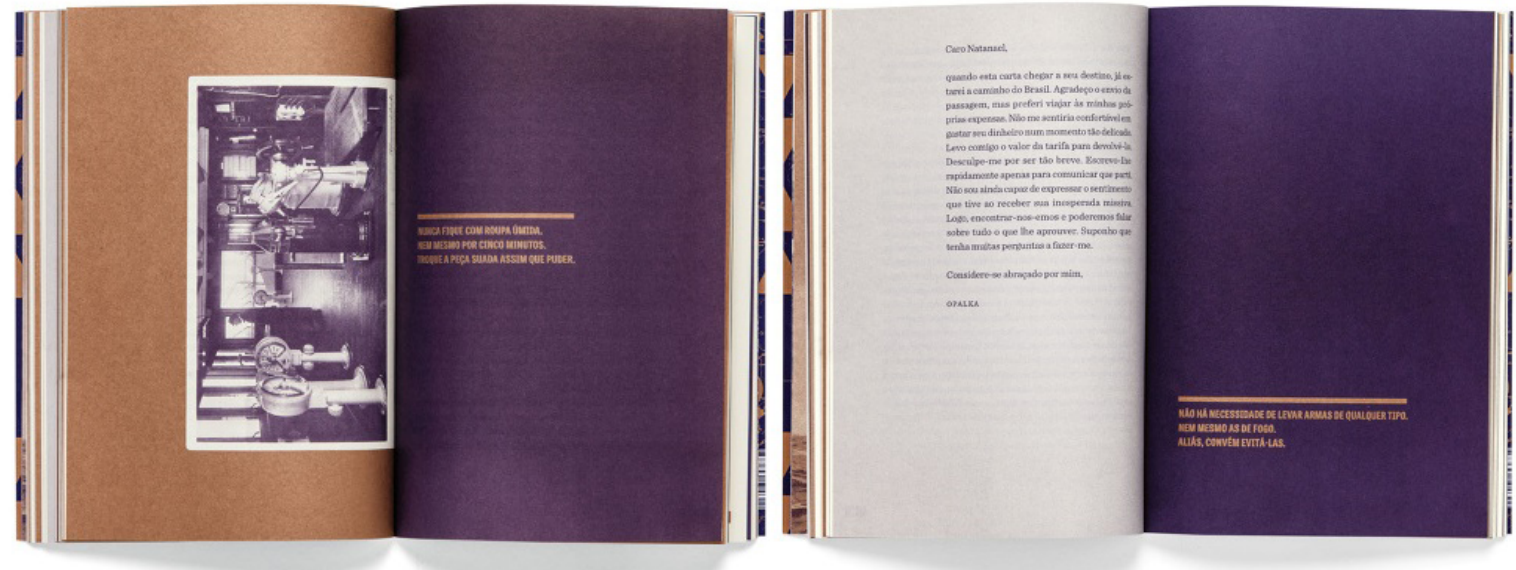

Figuras 1 e 2 - Opsanie Swiata, páginas internas

Fonte: Capturas fotográficas realizadas por nós das páginas do livro de STIGGER, 2013.

É somente ao final que é possivel entender o que esses elementos que parecem desconexos representam nessa combinação entre um romance e um diário de viagens. Espera-se, desse leitor, que, se ele não tenha o repertório para reconhecer algumas das referências, pelo menos leia a obra até alcançar o paratexto final, uma lista de "Deveres" (Figura 3).
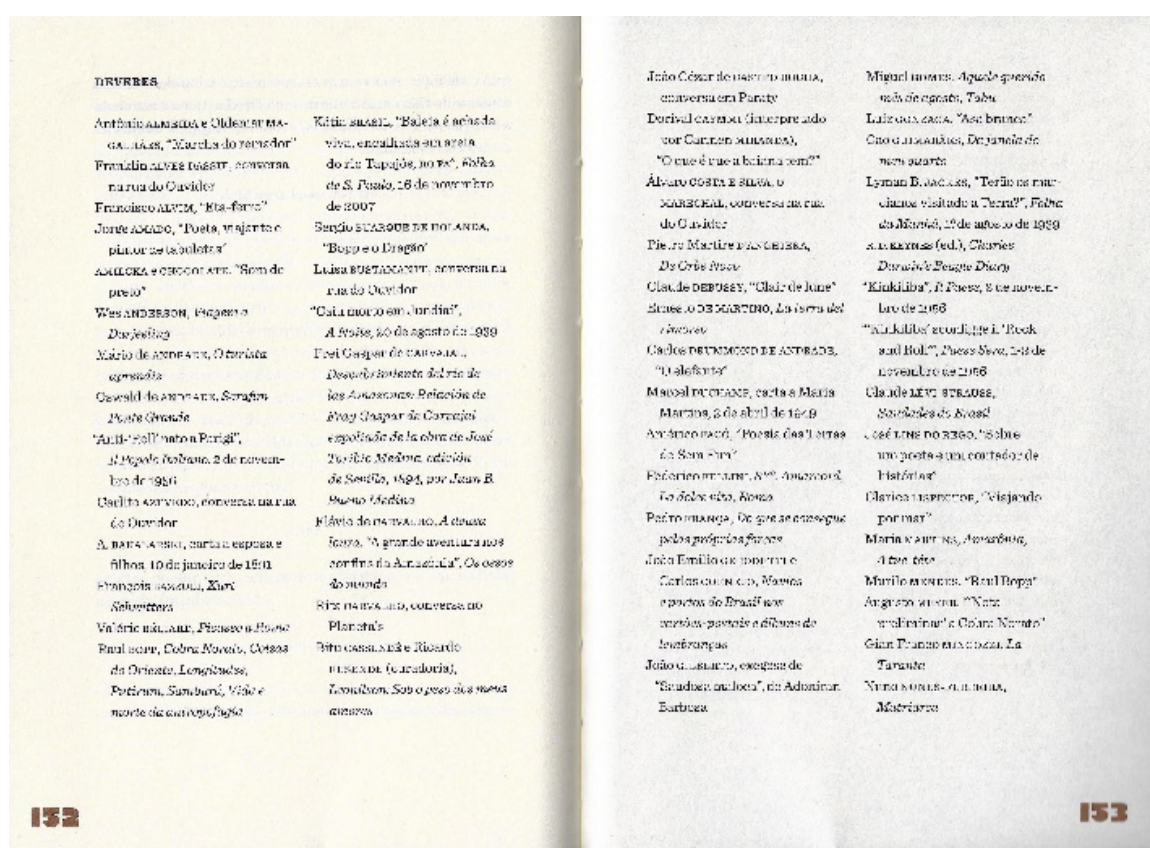

Figura 3 - Opsanie swiata, Lista de deveres

Fonte: Capturas fotográficas realizadas por nós das páginas do livro de STIGGER, 2013.

Nela, a autora relaciona todos os intertextos que usou para escrever o romance - outros romances, contos, obras de arte visual, canções, mas também, por exemplo, diálogos com pessoas em diferentes partes do mundo. Encontramos muitas referências do Modernismo, por exemplo, Serafim Ponte Grande, de Oswald de Andrade, O turista aprendiz, de Mário de Andrade, Cobra Norato, de Raul Bopp. E então entendemos que o personagem Bopp talvez seja uma representação do próprio escritor cuja obra também é referência. Até aqui, embora se tratem, alguns deles, de outros produtos de midia, como o filme Viagem a Darjeeling, de Wes Andersen, podemos entender esse fenômeno 
como intertextual, visto que é o conteúdo deles - não a mídia - que importa na representação.

No entanto, o processo que ali se constrói é metaficcional, porque é preciso que o leitor trace outra importante relação esboçada pelo produto de mídia, através do título e do nome do protagonista. E é somente através da compreensão da obra como um fenômeno intermidial que se dá a significação em toda a sua intenção, como estratégia. Opalka é o nome de um famoso pintor polonês (1931-2011), e aqui podemos vê-lo pintando uma de suas obras, através do desenho de pequenas letras (Figura 4).

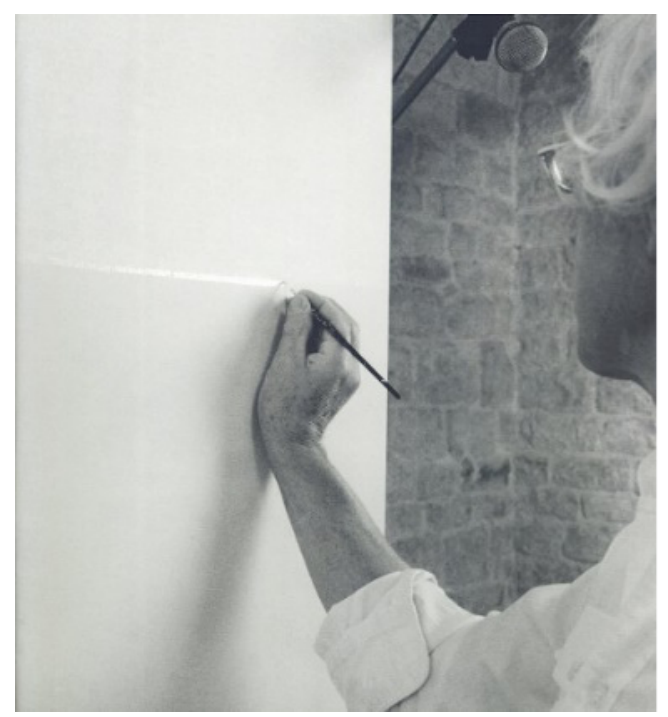

Figura 4 - Octogone, Opalka

Fonte: Centre de Création Contemporaine Olivier Debré ${ }^{8}$.

Enquanto Opalka (d)escreve o mundo através de letras em sua pintura, o romance imita a pintura de Opalka, descrevendo o mundo através de palavras - nessa pintura-romance, as letras são esse imenso tecido de citações. É um produto de mídia cuja estrutura faz referência à estrutura de outra midia qualificada, a pintura, ou mesmo de outro produto de mídia, se pensarmos a pintura de Opalka. A metaficção parece estar aqui para falar sobre como as artes são sempre criações transtextuais, intermidiais. E também nos leva a pensar sobre como a literatura descreve o mundo usando sempre as mesmas vinte e seis letras que Opalka usa para pintar, tecendo uma interessante associação entre a escritura e a pintura. Para a Intermidialidade, o romance de Stigger é uma representação complexa de outra mídia, tão metafórica em sua representação, que podemos entender como uma imitação, ou um como se, na ideia de Rajewsky (2012).

É através desses dois exemplos que entendemos que muitas vezes, sobretudo nas obras contemporâneas que se aproveitam das convergências hoje possiveis no universo da edição, os estudos em Intermidialidade são fundamentais para a compreensão da literatura. É importante apontar que ambas obras exigem leitores competentes, informados e dispostos a buscar e a tecer relações. Em Divórcio, a metaficção é, como fenômeno intermidial, uma estratégia para corroborar a crítica ao modo como a realidade pode ser representada pela escrita, por isso a necessidade de fazer o próprio romance ser representado. No caso da autoficção, é o que é: confundem-se as instâncias do real e da invenção - não por invocação da memória ou das experiências, inerentes à literatura, mas pela forjação de memórias e experiências como estratégia de escritura - e a resposta do leitor de nosso tempo é a esperada. A realidade, assim, precisa ser trazida a partir de mídias indiciais.

Não tão intensos e íntimos quanto Lísias, há vários outros exemplos da escrita autoficcional na literatura brasileira contemporânea: Marcelo Mirisola, Márcia Denser, Sergio Sant'Anna, Cristóvão Tezza, Michel Laub, Noemi Jaffe, Conceição Evaristo, Bernardo Carvalho. Bernardo Carvalho, objeto de nossos estudos das tendências da literatura contemporânea, faz confundir, através da autoficção, seu exercício como jornalista ao de autor de romances. E é através desse agenciamento como jornalista, repórter ou investigador de histórias, que ele traça seus personagens moventes, sempre a buscar uma verdade escondida no não contado. Em Noves noites, por exemplo, é através de uma notícia de jornal que o narrador-protagonista passa a investigar a vida de seu personagem, um ser pouco ficcional. Lemos na contracapa do livro (Companhia da Letras, 2006, $7^{\text {a }}$ reimpressão): 
"Nove noites mistura fatos da vida do antropólogo norte-americano Buel Quain - que viveu entre os indios Krahô, no Tocantins, e se matou em 1939. aos 27 anos - com as elucubrações do narrador." É essa a mistura típica da autoficção, apesar da não identificação nominal entre o narrador e o autor, pois a narrativa se coloca como jornalistica, investigativa. Em outra edição (Companhia das Letras, 2004), essa relação autoficcional se intensifica, pois há a inserção de uma fotografia do autor, Bernardo Carvalho, quando criança, ao lado de um índio, no Tocantins. Essa mesma imagem acaba por ser a capa da edição de 2015. uma estratégia intermidial que mostra como o mercado livreiro está atento aos movimentos e interesses dos leitores.

A temática da própria escrita e da escrita como procedimento artístico - a descrição do mundo que é pintura e escritura - também tem sido um fenômeno recorrente nos produtos de mídia contemporâneos, vide o cinema com as técnicas da quebra da quarta parede e os planos sequência one-shot, bastante comuns nas séries de televisão, a exemplo da série Demolidor (Netflix, 2015-2018). A consciência sobre o processo de escrita, talvez muito relacionada ao grande número de oficinas de escrita literária que se tem proliferado pelo Brasil, se mostra não apenas nessa discussão sobre a ficção que caracteriza a metaficção, como nas obras $A$ resistência, de Julián Fuks, Nove noites, de Bernardo Carvalho, e Quarenta dias, de Valéria Rezende, mas também no modo como narradores usam os sinais gráficos para distinguir personagens e narradores, a inclusão de diários e cartas e a divisão em capítulos, uns fazendo referência a outros.

Esse atravessamento entre as mídias, possivel pela porosidade da literatura, que é capaz de transmidiar imagens, sons e sensações em palavras, certamente tem bastante sentido no tipo de texto que temos acessado de forma ubíqua - a hipermídia. É na internet que está essa mistura como uma nova forma, que nega as molduras dos gêneros e mesmo a ideia de mídia e linguagem. Assim, outra perspectiva bastante pertinente para pensarmos a literatura está nas relações intermidiais que ela estabelece com outras formas da cultura e da arte. No entanto, por mais que essa transformação faça obnubilar suas molduras, o romance segue sendo a narrativa de um eu - menos ou mais opaco, menos ou mais parcial, menos ou mais focalizado em si mesmo, mas sempre um sujeito instalado em seu tempo, seja para negá-lo, seja para afirmá-lo. Pensar as tendências da literatura contemporânea certamente evoca também a observação do sujeito que lê e dos modos como esse leitor tem buscado satisfazer seu desejo por histórias, por mitos, por símbolos - e talvez lembrar um antigo ditado popular: o artista está onde o povo está.

\section{Referências}

BARTHES, Roland. A câmara clara. Tradução de Júlio Castañon Guimarães. Rio de Janeiro: Nova Fronteira, 1984

BAUMAN, Zygmunt. O mal-estar da pós-modernidade. Tradução de Mauro Gama e Cláudia Martinelli Gama. Rio de Janeiro: Zahar, 1998.

BOURRIAUD, Nicholas. Pós-produção: como a arte reprograma o mundo contemporâneo. São Paulo: Martins, 2009

CARR, Nicholas G. A geração superficial: o que a internet está fazendo com os nossos cérebros. Rio de Janeiro: Agir, 2011. https://doi.org/10.1590/s010244502012000100010

CARVALHO, Bernardo. Nove noites. São Paulo: Companhia das Letras, 2002. https://doi. org/10.17851/235.-0076.25.34.241-243

DALCASTAGNĖ, Regina Literatura brasileira contemporânea: um território contestado. Vinhedo: Horizonte, 2012.

DEBORD, Guy. A sociedade do espetáculo. Rio de Janeiro: Contraponto, 1997

DOMINGOS, Ana Cláudia Munari; HOHLFELDT, Antonio. O narrador na cultura digital. In: COMUNICAÇÃO IBERO-AMERICANA: OS DESAFIOS DA INTERNACIONALIZAÇÃO - II CONGRESSO MUNDIAL DE COMUNICAÇÃO IBERO-AMERICANA, Braga. Anais ... Braga, Portugal: CECS, 2014, p. 194-203. https://doi. org/10.5151/despro-sigradi2015-60183

ELESTRÖM, Lars. Midialidade: ensaios sobre comunicação, semiótica e intermidialidade. Organizadoras Ana Cláudia Munari Domingos, Ana Paula Klauck, Glória Maria Guiné de Melo. Porto Alegre: EDIPUCRS, 2017.

FIGUEIREDO, Euridice. Mulheres ao espelho: autobiografia, ficção, autoficção. Rio de Janeiro: EdUERJ, 2013. 
GARCIAA-CAPILLA, Diego. La Generación Me em los discursos comunicacionales: la perpspectiva de la ética postmoderna. In: TORRADO, Suzana; RÓDENAS, Gabri; FERRERAS, José Gabriel. Yo, me, mi, conmigo: el triunfo de la Generation Me en los discursos comunicacionales. Zamora: Comunicación Social: Ediciones y publicaciones, 2011. https://doi. org/10.5565/rev/ap.62

HOHLFELDT, Antonio Carlos; DOMINGOS, Ana Cláudia Munari; SILVA, Taíssi Alessandra Cardoso. Discutindo Divórcio entre literatura, jornalismo e ética: um caso não só literário. Estudos de literatura brasileira contemporânea, n. 51, p. 83-97, maio/ago. 2017. https://doi.org/10.1590/2316-4018515

JENKINS, Henry. Textual poachers. Television fans e participatory culture. New York, London: Routledge, 1992. https://doi.org/10.4324/9780203114339

JENKINS, Henry. Transmedia Storytelling. Moving characters from books to films to video games can make them stronger and more compelling. Technological Review, [S. l.], 15 jan. 2003. Disponivel em: http://www.technologyreview.com/news/401760/ transmedia-storytelling/. Acesso: mar. 2015.

LASCH, Christopher. O mínimo eu: sobrevivência psíquica em tempos dificeis. São Paulo: Brasiliense, 1987.

LIPOVETSKY, Gilles. A felicidade paradoxal: ensaio sobre a sociedade do hiperconsumo. Lisboa: Galimard, 2006. https://doi.org/10.14195/0870-4147_46_28

LIPOVETSKY, Gilles. O capitalismo estético na era da globalização. Lisboa: Edições 70, 2014. https://doi. org/10.17231/comsoc.28(2015).2292

LÍSIAS, Ricardo. Divórcio. Rio de Janeiro: Objetiva, 2013

LYOTARD, Jean-François. A condição pós-moderna Rio de Janeiro: José Olimpio, 2010.

RAJEWSKY, Irina O. Intermidialidade, intertextualidade e "remediação": Uma perspectiva literária sobre intermidialidade. Trad. de Thaïs F. N. Diniz e Eliana Lourenço de Lima Reis. In: DINIZ, T. F. N. (org.). Intermidialidade e estudos interartes. Desafios da arte contemporânea. Belo Horizonte: UFMG, 2012a. p. 15-45. https:// doi.org/10.5151/phypro-intermidialidade2014-034

RAJEWSKY, Irina O. A fronteira em discussão: o status problemático das fronteiras midiáticas no debate contemporâneo sobre intermidialidade. In: DINIZ,

T. F. N.; VIEIRA, A.S. (org.). Intermidialidade e estudos interartes. Desafios da arte contemporânea 2. Belo Horizonte: UFMG, 2012b. p. 51-74.

REVISTA CULT. Revista Cult entrevista Ricardo Lisias. S/D. Disponivel em: http://revistacult.uol.com.br/ home/2014/og/tv-cult-entrevista-ricardo-lisias_. Acesso em: out. 2016.

SANTAELLA, Lucia. Comunicação ubiqua: repercussões na cultura e na educação. São Paulo: Paulus, 2013

STIGGER, Verônica. Opsanie Swiata. São Paulo: Cosac Naify, 2013.
TORRADO, Suzana; RÓDENAS, Gabri; FERRERAS, José Gabriel. Prólogo. In: TORRADO, Suzana; RÓDENAS, Gabri; FERRERAS, José Gabriel. Yo, me, mi, conmigo. El triunfo de la Generation Me en los discursos comunicacionales. Zamora: Comunicación Social Ediciones y publicaciones, 2011. https://doi. org/10.5565/rev/qp.62

\section{Endereço para correspondência}

Ana Cláudia Munari Domingos

Av. Independência, 2293

Universitário, 96815-900

Santa Cruz do Sul, RS, Brasil 